\title{
Mapping data on Indonesia's worst forest and land fires of palm oil cultivation lands
}

\author{
Evi Frimawaty ${ }^{1 *}$ \\ ${ }^{1}$ School of Environmental Science, Universitas Indonesia, Central Jakarta, DKI Jakarta, Indonesia, \\ 10440
}

\begin{abstract}
During the last semester of 2019, Indonesia was hit by major forest and land fires in Sumatera and Kalimantan. The culprit of a large number of smokes were palm oil cultivation lands. This study uses data collected from Aqua and Terra satellite of Nasa to visualize the hotspots' severity, causing some provinces to become smoky. The severe hotspots were located on Riau, West Kalimantan, and Central Kalimantan through visualization density. The hotspots detected in this study vary from 300 to 468 degrees Fahrenheit, shown by the brightness of visualized colors on the map. This study also found that the forest and land forest fires have reached its peak during August 2019.
\end{abstract}

\section{Introduction}

During the last semester of 2019, Indonesia was hit by major forest and land fires in Sumatera and Kalimantan. Purnomo et al. concluded that the most significant frequency of hotspots occurred in wood and palm oil plantations and logging concessions (47\%), followed by conservation areas $(31 \%)$ and community land $(22 \%)$ [1]. Forest and land fire management efforts to reduce fires that may affect life and livelihoods are needed. Especially for Oil palm plantation management, which requires an extensive area of land. Based on data from the Directorate General of Plants and Plantations, Ministry of Agriculture in 2018, the Indonesian oil palm's total area is 14.3 million hectares. To anticipate forest and land fires in the future, hotspot data at the time is needed.

Who will benefit from this data? Indonesia's central or local governments can use this data to avoid loss of rainforest. It is now possible for the government to know the specific locations and times where forest and land fires are most likely to occur. The central government must also start thinking about regulations that can prevent forest and land fires, both preventively and repressively.

How can this data be used for further insight and development of experiments? The data used in this study can be analyzed through other advanced methods (such as logistic regression, machine learning, and in-depth learning) to map the exact spatial patterns of forest and land fires over a period of time.

What is the added value of this data? This study is also useful for NGOs or activists concerned about clearing land for sustainable cultivation. There may be some irresponsible

\footnotetext{
* Corresponding author: evi.frimawaty11@ui.ac.id
} 
companies out there. However, the government will always promote sustainable ways of cultivating oil palm and punish irresponsible companies. Make it easier to prove companies that carry out forest and land fires.

\section{Method}

This study has been designed to visualize hotspots (forest fire points) during the forest and land fires in Indonesia during the second semester of 2019. The author used data from the satellite to monitor the severity of the hotpots through temperature estimates. The data earned from Global Forest Watch is in coordinate points (latitude and longitude) of every forest owned by local corporations. The coordinate points also contain the subdistrict, district, and province where the point is. The provinces visualized in this study are all provinces in the Sumatera and Kalimantan (Borneo) islands.

In this study, the author used density modeling available in the tableau to visualize hotspots in several Indonesian provinces. Density modeling visualize recorded coordinate points within the same sub-district to map the satellite's temperatures. The density modeling visualizes several coordinates on the same sub-district into a single circle. The single circle can be recolored with gradient effects to mark the intensity of the measured variable.

The temperature (or brightness) then can be visualized under the Sum or Average function to recolor the circles visualized by the software $[2,3]$. In this study, the average function has been used to avoid confusion on the interactive dashboard caused by Sum functions since, in Sum functions, there will be some possible same-colorization. However, the measured density is different across regions. The average function measures several hotspots' average temperatures within the same sub-districts [4]. After the hotspots' temperatures have been averaged, the density model of visualization has been used to map where most hotpots are agglomerated. The high brightness (lemon yellow, or nearly white color) indicates a high density of the hotspots. In other words, the region (or subregion) contains most hotspots compared to surrounding regions - the high-density results in a higher temperature average. On the other hand, the low brightness (red and dark red) indicates a low density of the hotspots. The low-density regions have a lower temperature average than the high one. Yet, the individual temperature of the hotspots still high for living beings.

This study uses open-source data gathered from AQUA satellite (NASA's satellite to observe the weather, water bodies, precipitation) and TERRA satellite (NASA's satellite to observe multi-discipline aspects on earth) [5-7]. The satellite data used in this study was obtained through the Global Forest Watch [8-10]. In this study, the author tried to map the severity of hotspots in several provinces in Indonesia during forest and land fires in the 3rd to 4th quarter of 2019. In this study, the author visualizes the temperature of detected hotspots in Sumatera and Kalimantan island. The temperature data were stated in degrees of Fahrenheit.

This study will focus on the satellite data, with the time range between 1st of June 2019 to 30 th of November 2019. In this study, the dataset is a long format (instead of wide) due to longitudinal analysis of coordinate points across times $[11,12]$. The author has used excel to preview the data and used StataMP 14 to manage many rows inefficiently [13-15]. The visualization has been made with Tableau Public Edition to map hotspots between the time range [16].

This study's time range refers to the national news when forest and land fires become major national headlines in various newspapers. The forest and land fire itself become major headlines from August to October 2019. The time range (as mentioned before) was 
chosen to accommodate the pre-burning and post-burning phase to visualize hotspots in a normal timeline (not only on the hype or climax phase).

\section{Results and discussion}

According to the data obtained from the satellite, Lampung, Jambi, and South Sumatera province has the highest average brightness during the land and forest fires. Below is the summary statistics table of the brightness on provinces (Table 1) included in this study:

Table 1. Mean of Temperature by Province, sorted. (Author, 2020)

\begin{tabular}{|l|c|c|c|}
\hline \multicolumn{1}{|c|}{ Province } & $\begin{array}{c}\text { Mean of Brightness } \\
\text { (Degrees Fahrenheit) }\end{array}$ & Std. Deviation & Freq. \\
\hline Lampung & 326.55 & 21.82 & 38 \\
\hline Jambi & 325.38 & 18.51 & 209 \\
\hline South Sumatera & 325.05 & 16.06 & 194 \\
\hline West Kalimantan & 323.52 & 17.99 & 1,571 \\
\hline Central Kalimantan & 322.42 & 16.96 & 946 \\
\hline West Sumatera & 322.22 & 9.33 & 12 \\
\hline North Sumatera & 321.00 & 6.32 & 3 \\
\hline Aceh & 319.53 & 5.96 & 4 \\
\hline East Kalimantan & 319.39 & 11.50 & 365 \\
\hline South Kalimantan & 318.62 & 14.52 & 155 \\
\hline Riau & 317.17 & 12.69 & 567 \\
\hline Riau Island & 317.06 & 2.65 & 5 \\
\hline Bengkulu & 315.83 & 6.44 & 16 \\
\hline
\end{tabular}

Notes: North Kalimantan Weren't included due to provincial expansion since 2015. The province data from Global Forest Watch weren't updated with this change

During the land and forest fires in Indonesia, the Lampung province was the hottest province (on average) with an average temperature of 326.5 degrees Fahrenheit, compared to the other provinces. On the second and third, Jambi and South Sumatera followed it with around 325.38 and 325.05 degrees of Fahrenheit, respectively. The result also shows that West Kalimantan has the most hotspots than the other provinces, with a total of 1,571 hotspots recorded by the satellite. Central Kalimantan and Riau Province have the second and third-biggest hotspots, with 946 and 567 hotspots. To have a detailed spatial analysis, the authors also summarize the district level in the following Table 2.

Table 2. Summary Statistics on the District Level sorted (Author, 2020)

\begin{tabular}{|l|c|c|l|c|c|}
\hline \multicolumn{1}{|c|}{ District } & $\begin{array}{c}\text { Average } \\
\text { Temperature } \\
\text { (Fahrenheit) }\end{array}$ & $\begin{array}{c}\text { Std. } \\
\text { Deviation }\end{array}$ & \multicolumn{1}{|c|}{ District } & $\begin{array}{c}\text { Average } \\
\text { Temperature } \\
\text { (Fahrenheit) }\end{array}$ & $\begin{array}{c}\text { Std. } \\
\text { Deviation }\end{array}$ \\
\hline Tanah Laut & 332.26 & 30.81 & $\begin{array}{l}\text { Pesisir } \\
\text { Selatan }\end{array}$ & 318.52 & 9.98 \\
\hline $\begin{array}{l}\text { Hulu Sungai } \\
\text { Tengah }\end{array}$ & 331.93 & 6.94 & Tapin & 318.13 & 10.83 \\
\hline Sambas & 330.42 & 20.80 & $\begin{array}{l}\text { Bengkulu } \\
\text { Utara }\end{array}$ & 318.01 & 6.47 \\
\hline
\end{tabular}




\begin{tabular}{|c|c|c|c|c|c|}
\hline $\begin{array}{l}\text { Barito } \\
\text { Timur }\end{array}$ & 330.10 & 27.80 & Batang Hari & 317.94 & 9.61 \\
\hline Seruyan & 327.39 & 20.42 & $\begin{array}{l}\text { Kota } \\
\text { Pontianak }\end{array}$ & 317.71 & 10.18 \\
\hline Balangan & 327.30 & 13.61 & $\begin{array}{l}\text { Tanjung } \\
\text { Jabung } \\
\text { Barat }\end{array}$ & 317.65 & 3.18 \\
\hline $\begin{array}{l}\text { Muaro } \\
\text { Jambi }\end{array}$ & 327.10 & 18.96 & Lamandau & 317.58 & 7.22 \\
\hline $\begin{array}{l}\text { Tulang } \\
\text { Bawang }\end{array}$ & 326.90 & 22.01 & $\begin{array}{l}\text { Kotawaringi } \\
\text { n Barat }\end{array}$ & 317.13 & 8.73 \\
\hline $\begin{array}{l}\text { Ogan } \\
\text { Komering } \\
\text { Ilir }\end{array}$ & 326.77 & 16.45 & $\begin{array}{l}\text { Dharmas } \\
\text { Raya }\end{array}$ & 316.60 & 0.00 \\
\hline Sintang & 326.05 & 15.39 & Kampar & 316.60 & 0.00 \\
\hline Sanggau & 325.56 & 16.84 & Bengkalis & 316.53 & 13.02 \\
\hline Kota Baru & 325.48 & 4.48 & $\begin{array}{l}\text { Gunung } \\
\text { Mas }\end{array}$ & 316.25 & 13.81 \\
\hline Sekadau & 325.39 & 13.07 & $\begin{array}{l}\text { Kota } \\
\text { Tanjung } \\
\text { Pinang }\end{array}$ & 316.20 & 0.00 \\
\hline Bungo & 324.59 & 8.91 & Malinau & 316.20 & 4.55 \\
\hline Ketapang & 324.29 & 19.12 & Katingan & 315.85 & 8.88 \\
\hline Nagan Raya & 323.70 & 3.96 & $\begin{array}{l}\text { Indragiri } \\
\text { Hilir }\end{array}$ & 315.84 & 10.83 \\
\hline Pontianak & 322.46 & 19.50 & Siak & 315.83 & 12.71 \\
\hline Landak & 321.85 & 14.91 & Barito Utara & 315.67 & 13.65 \\
\hline Bulongan & 321.69 & 13.01 & $\begin{array}{l}\text { Musi Banyu } \\
\text { Asin }\end{array}$ & 315.65 & 7.47 \\
\hline $\begin{array}{l}\text { Kapuas } \\
\text { Hulu }\end{array}$ & 321.55 & 21.41 & Rokan Hulu & 315.65 & 5.16 \\
\hline Musi Rawas & 321.49 & 14.82 & Ogan Ilir & 315.53 & 1.14 \\
\hline $\begin{array}{l}\text { Indragiri } \\
\text { Hulu }\end{array}$ & 321.35 & 13.45 & Rokan Hilir & 315.31 & 10.71 \\
\hline Berau & 321.26 & 10.52 & $\begin{array}{l}\text { Labuhan } \\
\text { Batu }\end{array}$ & 315.30 & 0.00 \\
\hline Pasir & 320.50 & 10.37 & $\begin{array}{l}\text { Tanah } \\
\text { Bumbu }\end{array}$ & 314.70 & 10.35 \\
\hline $\begin{array}{l}\text { Kotawaringi } \\
\text { n Timur }\end{array}$ & 320.46 & 12.68 & Nunukan & 313.87 & 6.88 \\
\hline Kutai Barat & 320.40 & 14.56 & $\begin{array}{l}\text { Lampung } \\
\text { Tengah }\end{array}$ & 313.60 & 0.00 \\
\hline $\begin{array}{l}\text { Kutai } \\
\text { Kartanegara }\end{array}$ & 320.24 & 10.77 & Lingga & 313.50 & 0.00 \\
\hline $\begin{array}{l}\text { Pulang } \\
\text { Pisau }\end{array}$ & 320.16 & 13.88 & $\begin{array}{l}\text { Kuantan } \\
\text { Singingi }\end{array}$ & 312.30 & 0.00 \\
\hline Sarolangun & 319.90 & 0.00 & $\begin{array}{l}\text { Kota } \\
\text { Subulussala } \\
\mathrm{m}\end{array}$ & 312.10 & 0.00 \\
\hline $\begin{array}{l}\text { Barito } \\
\text { Selatan } \\
\end{array}$ & 319.82 & 12.71 & Kutai Timur & 311.46 & 9.47 \\
\hline Kapuas & 319.70 & 12.50 & Seluma & 310.85 & 3.89 \\
\hline
\end{tabular}




\begin{tabular}{|l|c|c|l|c|c|}
\hline Pelalawan & 319.66 & 14.89 & $\begin{array}{l}\text { Kota } \\
\text { Singkawang }\end{array}$ & 310.57 & 7.16 \\
\hline Melawi & 319.37 & 14.81 & Sukamara & 310.06 & 4.65 \\
\hline Bengkayang & 319.34 & 6.54 & $\begin{array}{l}\text { Muko- } \\
\text { Muko }\end{array}$ & 309.40 & 1.41 \\
\hline
\end{tabular}

After the density visualization modeling has been done, the author comes up with Figure 1. From the visualization in Figure 1, it is known that West Kalimantan, Central Kalimantan, and Riau province has the most hotspots shown by a large amount of brightness. Compared to Sumatera Island, Kalimantan has more hotspots and a higher temperature average during land and forest fire in 2019. The highest average temperature recorded was 468.2 degrees Fahrenheit in West Kalimantan Province, in Kapuas Hulu District. The place also has the highest density among the other regions, indicating severe fires and smoke produced within. To confirm this finding, the author tried to match severe smoke news in West Kalimantan to match whether the satellites' estimates are correct.

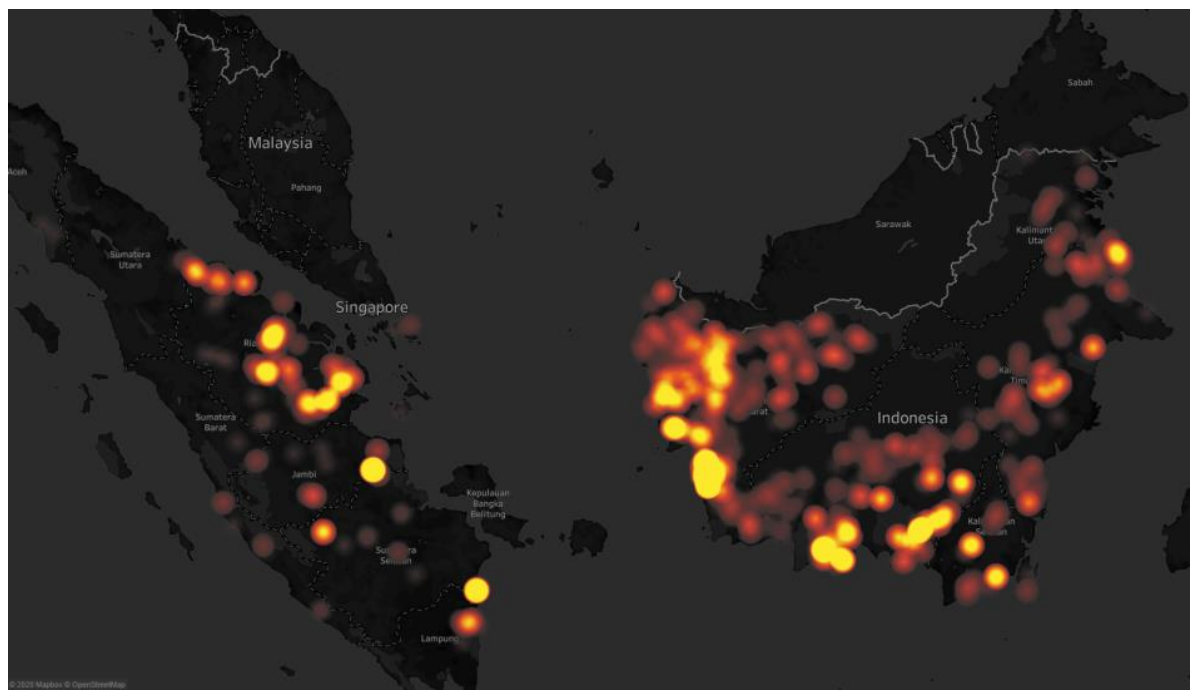

Fig. 1. Hotspot visualization from Terra and Aqua Satellites during June-November 2019 (Author, 2020)

To achieve a deeper analysis of the hotspots, the author tried to breakdown the timeline by each month. We will know when (month) the hotspot reached its maximum point by filtering the time frames. This condition can be seen in Figure 2 to Figure 8 . The images in Figure 2 to Figure 8 show that forest fires have peaked in August 2019, where most hotspots were located in Riau and West Kalimantan Province. 


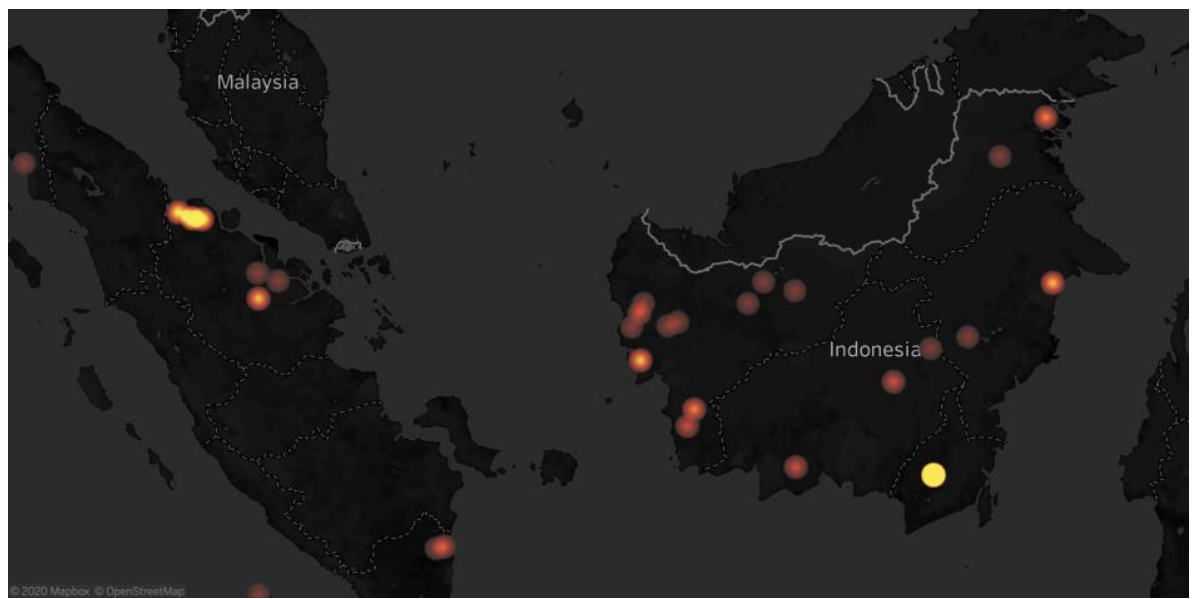

Fig. 2. Hotspot visualization from Terra and Aqua Satellites on June 2019 (Author, 2020)

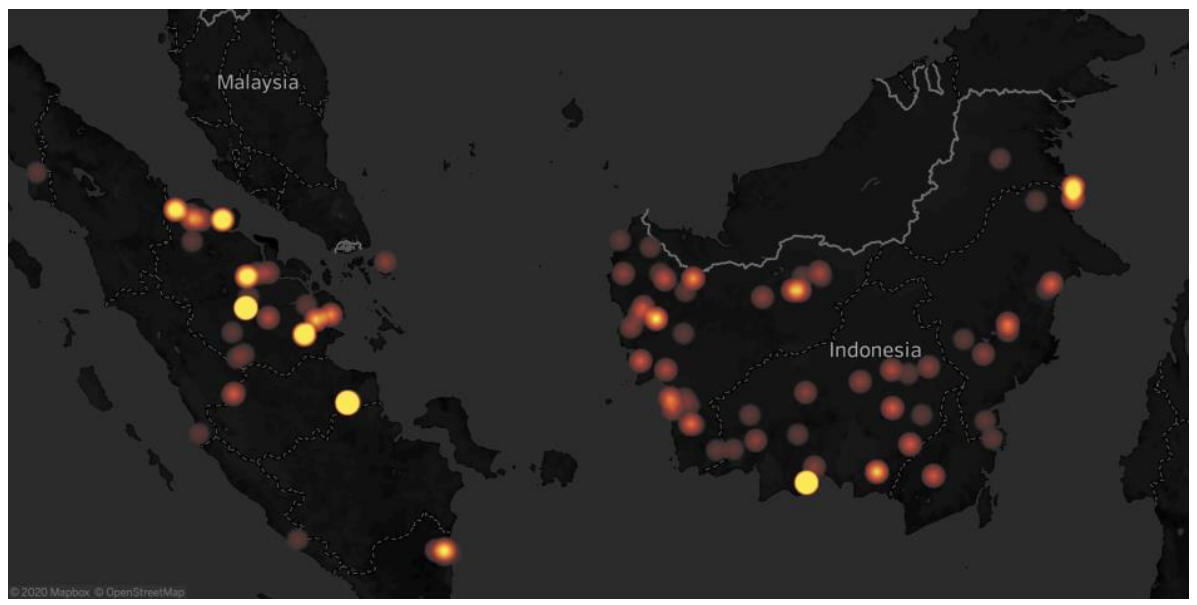

Fig. 3. Hotspot visualization from Terra and Aqua Satellites on July 2019 (Author, 2020)

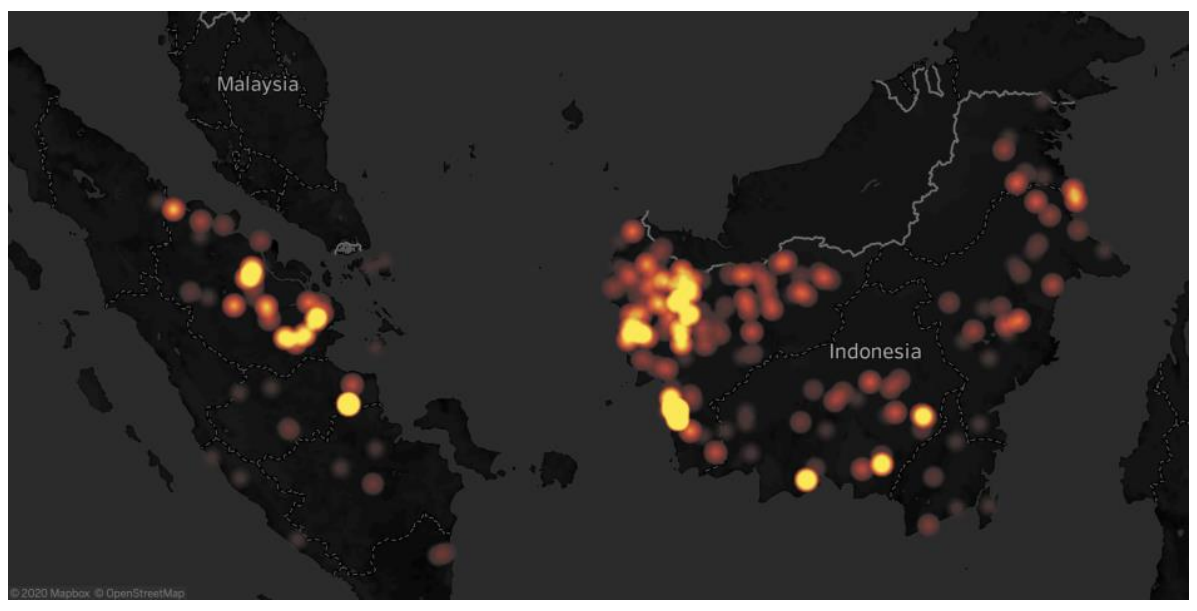

Fig. 4. Hotspot visualization from Terra and Aqua Satellites on August 2019 (Author, 2020) 


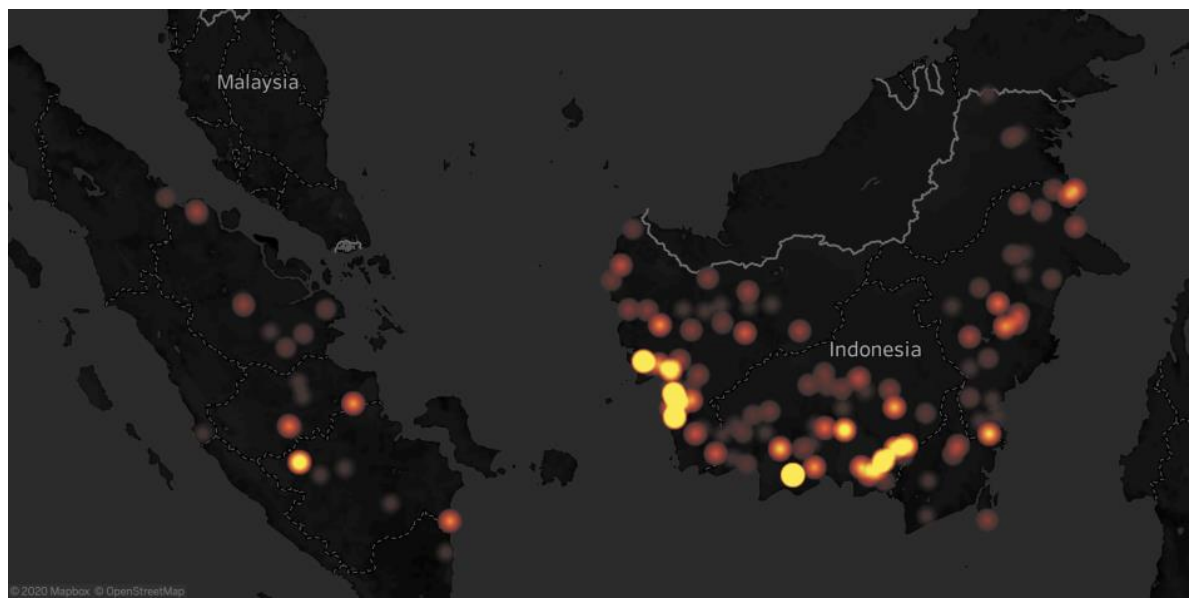

Fig. 5. Hotspot visualization from Terra and Aqua Satellites on September 2019 (Author, 2020)

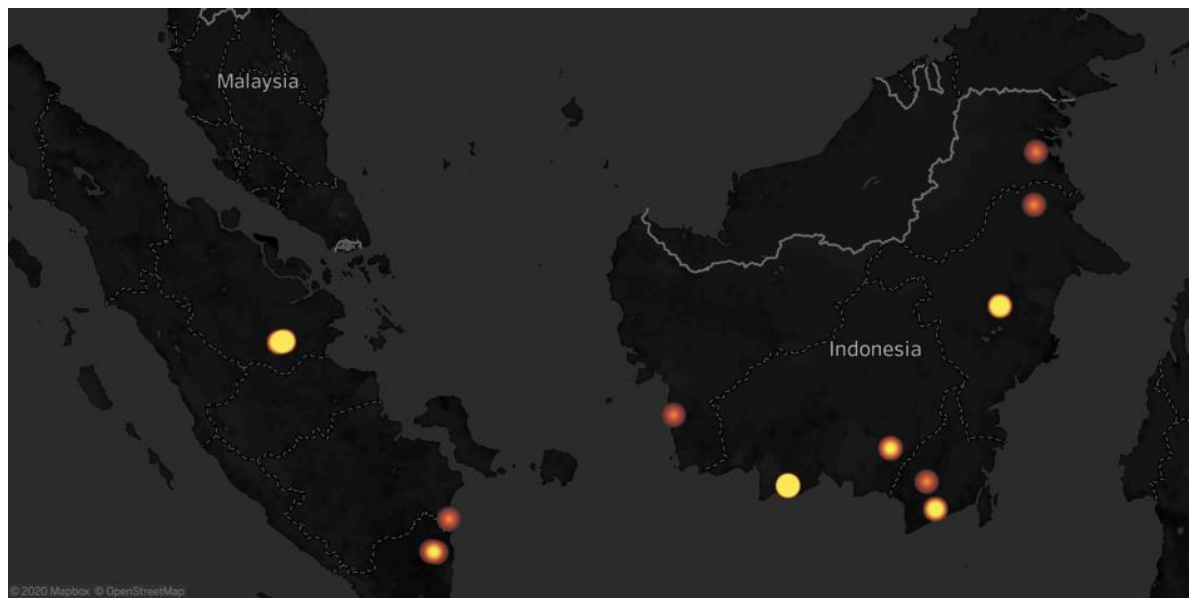

Fig. 6. Hotspot visualization from Terra and Aqua Satellites on October 2019 (Author, 2020)

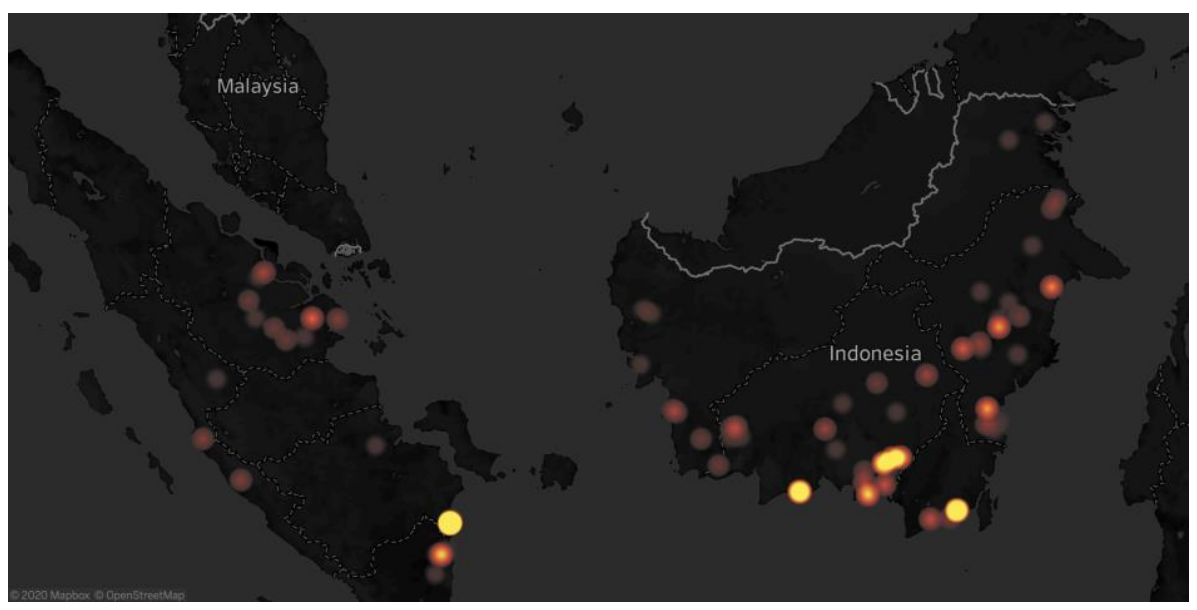

Fig.7. Hotspot visualization from Terra and Aqua Satellites on November 2019 (Author, 2020) 


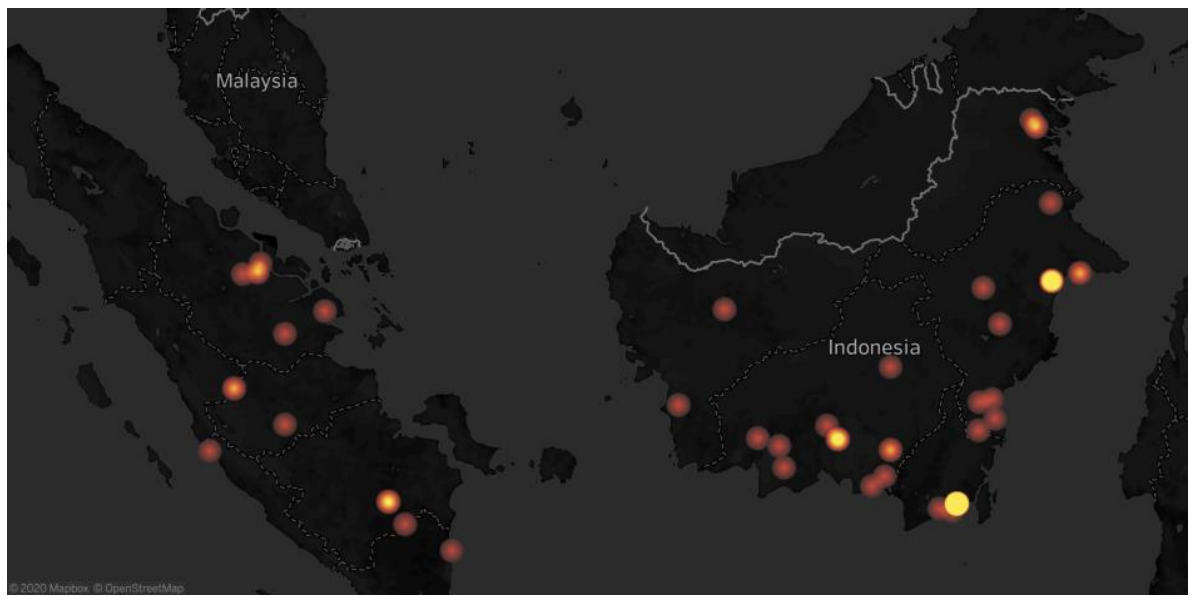

Fig. 8. Hotspot visualization from Terra and Aqua Satellites on December 2019 (Author, 2020)

This study does not visualize the smokes (and/or smokes direction) due to data availability. Hence, the smoke produced by the hotspots is the limitation of this study. This study is also limited to a certain period (as mentioned above) and limited to palm oil cultivation lands that have been suspected as the hotspots during 2019 in Indonesia. More spatiotemporal analysis will be required in the future $[17,18]$.

\section{Conclusion}

Hot spots occur on every type of land use and tenure in Indonesia. The hotspots detected in this study vary from 300 to 468 degrees Fahrenheit, shown by the brightness of visualized colors on the map. This study also found that the forest and land forest fires have reached its peak during August 2019.

\section{Acknowledgements}

This study is supported by the International research collaboration grant- Universitas Indonesia 2019, with contract number NKB-1959/UN2.R3.1/HKP.05.00/2019. The authors are in debt to H.A Adinegoro, who helped edit this article. The authors also thank the Global Forest Watch for giving reliable real-time data captured from Terra and Aqua Satellite.

\section{References}

1. H. Purnomo, B. Okarda, B. Shantiko, R. Achdiawan, A. Dermawan, H. Kartodihardjo, A. A. Dewayani, Forest and land fires, toxic haze and local politics in Indonesia, Int. For. Rev. 21, 486 (2019) https://doi.org/10.1505/146554819827906799

2. C. Yuan, Z. Liu, Y. Zhang, Fire detection using infrared images for UAV-based forest fire surveillance, in 2017 Int. Conf. Unmanned Aircr. Syst. ICUAS 2017, IEEE, Miami, FL, USA, pp. 567-572 (2017) https://doi.org/10.1109/ICUAS.2017.7991306

3. H. Fang, S. Walton, E. Delahaye, J. Harris, D. A. Storchak, M. Chen, Categorical Colormap Optimization with Visualization Case Studies, IEEE Trans. Vis. Comput. Graph. 23, 871 (2017) https://doi.org/10.1109/TVCG.2016.2599214 
4. S. N. B. M. Said, E.-S. M. M. Zahran, S. Shams, Forest Fire Risk Assessment Using Hotspot Analysis in GIS, Open Civ. Eng. J. 11, 786 (2017)

https://doi.org/10.2174/1874149501711010786

5. V. V. Hnatushenko, V. V. Hnatushenko, D. K. Mozgovyi, V. V. Vasiliev, Satellite technology of the forest fires effects monitoring, Scientific Bulletin of National Mining University 70 (2016) ISSN 2071-2227

6. M. A. Matin, V. S. Chitale, M. S. R. Murthy, K. Uddin, B. Bajracharya, S. Pradhan, Understanding forest fire patterns and risk in Nepal using remote sensing, geographic information system and historical fire data, Int. J. Wildl. Fire 26, 276 (2017) https://doi.org/10.1071/WF16056

7. P. Goymer, Forest vision, Nat. Ecol. Evol. 1, 1 (2017) https://doi.org/10.1038/s41559$\underline{017-0097}$

8. K. V. Suresh Babu, A. Roy, P. R. Prasad, Forest fire risk modeling in Uttarakhand Himalaya using TERRA satellite datasets, Eur. J. Remote Sens. 49, 381 (2016) https://doi.org/10.5721/EuJRS20164921

9. P. G. Curtis, C. M. Slay, N. L. Harris, A. Tyukavina, M. C. Hansen, Classifying drivers of global forest loss, Science 361, 1108 (2018) https://doi.org/10.1126/science.aau3445

10. Y. Qin, T. Gartner, S. Minnemeyer, P. Reig, S. Sargent, Global Forest Watch Water Metadata Document (World Resources Institute, Washington D.C., 2016) http://agri.ckcest.cn/ass/NK005-20160919002.pdf

11. M. O. Jackson, P. Tebaldi, A Forest Fire Theory of the Duration of a Boom and the Size of a Subsequent Bust, SSRN Electron. J. 1 (2019) https://doi.org/10.2139/ssrn.2263501

12. S. Tian, Y. Wang, T. Cai, Study on calculating methods of forest fire area for dynamic disaster assessment based on infrared image, in AOPC 2017 Optical Sensing and Imaging Technology and Applications, Proc. SPIE, Beijing, China, pp. 104625J (2017) https://doi.org/10.1117/12.2285847

13. A. T. Filicetti, S. E. Nielsen, Fire and forest recovery on seismic lines in sandy upland jack pine (Pinus banksiana) forests, For. Ecol. Manage. 421, 32 (2018) https://doi.org/10.1016/j.foreco.2018.01.027

14. X. Cai, Improved Forest Fire Danger Rating Using Regression Kriging with the Canadian Precipitation Analysis (CaPA) System in Alberta, (University of Alberta, 2017)

15. E. J. Belval, C. D. O'Connor, M. P. Thompson, M. S. Hand, The Role of Previous Fires in the Management and Expenditures of Subsequent Large Wildfires, Fire 2, 57 (2019) https://doi.org/10.3390/fire2040057

16. B. Marielle, S. Couture, and S. M. Garcia, Insurance Demand against Forest Fire Risk: Empirical Analysis on French Private Forest Owners, SSRN Electron. J. 33, 0 (2012) https://doi.org/10.2139/ssrn.1800528

17. D. Sampurno, Spatiotemporal Analysis in Monitoring Landscape Dynamic Patterns in Tropical Peat Ecosystem (Study in Tebing Tinggi Island, Riau, Indonesia), J. Environ. Sci. Sustainable Dev. 2, 1 (2019) https://doi.org/10.7454/jessd.v2i1.33

18. Y.N. Lukito, The urban forest project as an extension of landscape immersion and a way to support community engagement in the Ragunan Zoo, Jakarta, ASEAN J. Community Engagement 2, 2 (2018) https://doi.org/10.7454/ajce.v2i2.135 